\title{
Biomechanical parameters for gait analysis: a systematic review of healthy human gait
}

\author{
Mary Roberts ${ }^{1 *}$, David Mongeon' and Francois Prince ${ }^{2}$
}

*Correspondence: mary.roberts@umontreal.ca

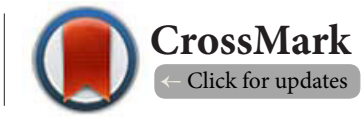

'Department of Kinesiology, University of Montreal, Montreal, Quebec, Canada.

${ }^{2}$ Faculty of Medicine, Department of Surgery, University of Montreal, Montreal, Quebec, Canada.

\begin{abstract}
Background: Modern gait analysis offers a broad variety of biomechanical parameters through which to quantify gait. However, no consensus has yet been established with regards to which biomechanical parameters are most relevant to evaluate during gait analysis in the healthy population.

Purpose: The purpose of the current systematic review was to determine the most relevant biomechanical parameters for gait analysis in the healthy adult population.

Methods: PubMed, EMBASE and Web of Science databases were searched. Two independent reviewers participated in the article selection and attributed a Level of Evidence score to each article to account for quality based on participant selection, intervention and analysis. A score combining both frequency and number of articles was calculated. Correlations were carried out between the Level of Evidence score, Journal Impact Factor and the frequency of biomechanical parameters.

Results: Spatio-temporal parameters were found to be the most often measured biomechanical parameters and reported by the greatest number of articles; walking velocity, cadence and step/stride length appearing to be the most relevant biomechanical parameters for gait analysis in the healthy adult population.

No correlation was found between Level of Evidence score and Journal Impact Factor, nor between the frequency of parameters and Level of Evidence score.
\end{abstract}

Conclusion: This systematic review provides recommendations for variables to assess in future gait evaluations in healthy adults.

Keywords: Gait, biomechanics, gait analysis, healthy, adult

\section{Introduction}

Walking is the most common form of locomotion and it is part of almost all activities of daily living $[1,2]$; therefore, the ability to walk is an indicator of overall health as it dictates autonomy [3]. Although walking is usually learned at a young age, the mechanics of walking are not as simple as they may appear [1].

From the first studies of human walking elaborated through a series of photographic images, by early Biomechanics enthusiasts Edweard Muybridge and Étienne-Jules Marey, gait analysis as it is known today has evolved significantly [4]. The walking pattern of individuals has become an area of broad interest and the focus of much research as seen by the numerous journals and articles published. The importance of gait analysis lies in its application; through years of research and experimentation, gait analysis has become widely used as a means to diagnose pathology, set a prognosis and establish and evaluate a treatment plan $[5,6]$. Today, a variety of different parameters of various types exist and are readily used to examine and explain human gait [7-10].

In clinical settings, gait analysis is often carried out solely through clinician observation [11]. Although clinicians have developed good expertise through many years of practice and training, these observations remain subjective [12]. Principal reason for main, and perhaps sole use of clinician observation as means of gait analysis, is ease of measurement $[8,13,14]$.

In the research setting, numerous parameters have been used to quantitatively describe gait. Parameters of various types such as spatio-temporal parameters, ground reaction forces, 
Roberts et al. Physical Therapy and Rehabilitation 2017,

http://www.hoajonline.com/journals/pdf/2055-2386-4-6.pdf

doi: 10.7243/2055-2386-4-6

joint kinematics and the energy expense are a few $[1,15,16]$.

In accordance with evidence-based-medicine, the biomechanical parameters chosen are as important as rigorous gait analysis technique [17]. Because of the quasi-infinite number of parameters available, it seems reasonable that certain parameters would be best suited for gait analysis in the healthy population.

Systematic reviews have been realized in an attempt to organize and add understanding to the practice of gait analysis in various populations. For example, a systematic review carried out by Sagawa and colleagues [18], using an original methodological approach, was able to identify the most relevant biomechanical parameters for assessing gait in individuals with a lower limb amputation. The results obtained by Sagawa and colleagues [18] leads to question whether the same biomechanical parameters are most relevant for gait analysis in the healthy adult population.

The aim of this systematic review is to determine the most relevant biomechanical parameters used for gait analysis in a healthy adult population. The term relevant was defined as those biomechanical parameters being able to identify gait abnormalities in the healthy adult population and applicable to the clinical and rehabilitation setting. This definition is an adaptation of that used by Sagawa et al. [18].

\section{Methods}

\section{Procedure for the identification of selected articles}

We performed an online search in three databases: PubMed, EMBASE and Web of Science. These three databases were selected for search because of their broad inclusion of multidisciplinary topics within the Biomedical and Health Sciences domain. Each database was searched for all years included in the respective databases with the last search completed in May 2016.

The following search was inputted to all three databases: [abstract/title] (speed OR cadence OR (stride time) OR (swing time) OR (step time) OR (single support time) OR (double support time) OR (foot flat time) OR (stance time ratio) OR (swing time ratio) OR timing OR (stride length) OR (step length) OR (step width) OR angle OR moment OR power OR (center of mass) OR (ground reaction force) OR (ground reaction impulse) OR (center of pressure) OR rotation OR symmetry OR velocity OR (stance phase) OR (swing phase) OR (cycle time) OR (spati* temporal) OR hip Or knee OR ankle OR foot) OR (biomechanic*) AND ([MeSH] gait OR walking OR locomotion).

In databases where applicable, certain additional parameters were used to narrow the search. In PubMed, filters including human studies of adults aged 18 to 65 years old, published in French and English and with regards to the nature of the study (i.e., original articles, review articles, case study) were applied. In the EMBASE and Web of Science databases, filters were applied to include human studies, French and English language publications and specific nature of study (i.e., original articles, review articles, case study).

\section{Inclusion and exclusion criteria}

The inclusion and exclusion criteria were developed based upon the purpose of the systematic review, to examine the biomechanical parameters used to study healthy gait. Thus, studies including participants living with pathologies, disabilities, health concerns and/or neurological deficits were excluded. To be selected, articles had to evaluate adults aged 18 to 65 years old with no walking aids. Participants could have been evaluated barefoot, wearing socks, wearing shoes and/or any combination of these three situations. As well, no studies were included if they measured the effect of a treatment or equipment. Selected articles had to at least evaluate participants walking at their self-selected speed on an overground and flat surface.

\section{Analysis of selected articles}

A census of all biomechanical parameters measured was undertaken by two evaluators by carefully reading and analyzing the chosen articles. First, all methodological aspects of the selected articles were tabulated and briefly summarized. Second, the biomechanical parameters measured in all articles were tallied. For each parameter, all articles which measured this parameter were reported and counted. Third, because of the many various instruments, techniques, planes of measurement, etc. used to quantify parameters in the studies selected, the parameters measured were summarized under broader parameter names (i.e. sagittal, frontal and transverse plane knee power were combined under the broader name of knee power).

Lastly, after a summation of parameters, the number of different articles measuring a type of biomechanical parameter was counted; this was also done for single parameters. Indeed, it seems inevitable to consider not only the most frequently measured parameters, but as well the number of different articles which measure a parameter to observe any disparities between the number of times a parameter was measured versus the number of different articles which measured this parameter.

In an attempt to evaluate relevance of biomechanical parameters, both the frequency of measure and the number of different articles which measure the parameter were combined to produce a score using the summarized parameters. For the first factor, all frequency of measurement scores were divided by the parameter having been measured the most times (hip power: 66 times) and multiplied by 0.5 . For the second factor, all number of articles were divided by the parameter having been measured by the most amount of different articles and multiplied by 0.5 . Both values were then added to obtain a score weighting both factors. It was deemed that both factors were as important as the other, each contributing to $50 \%$ of the score. The following is an example of the calculation for walking velocity, which was measured 50 times by 50 articles: Walking velocity: $((50 / 66) * 0.5)+\left((50 / 50)^{*} 0.5\right)=0.879$.

\section{Quality of selected articles}

We evaluated quality of the selected articles by attributing 
Roberts et al. Physical Therapy and Rehabilitation 2017,

a Level of Evidence score for each selected article. Our Level of Evidence score was a modified version of that used by Sagawa and colleagues [18], since they were interested in gait analysis in a population with a lower limb amputation and the current systematic review addresses healthy adult gait analysis. The 14 criteria were subdivided between three main article elements: 1) selection of participants, 2) intervention and assessment, and 3) statistical validity. The maximum possible score was therefore 14 , with each article receiving a score of 1 (if they met the requirements) or 0 (if they did not meet the requirements) for each criterion (score of 1 for a non-applicable criterion). Two independent evaluators assessed the score of all articles. For any disparities between scores, both evaluators determined the best suited scoring through discussion. If a consensus could not be reached by the two evaluators, a third evaluator intervened in order to break tie between both scores suggested.

\section{Data/ Statistical analysis}

A Spearman correlation was carried out in order to determine if higher Level of Evidence articles were published in higher Impact Factor journals. Also, a Spearman correlation was sought between the mean Level of Evidence attributed to all articles measuring a given parameter and its frequency of measurement. All statistical analyses were carried out using SPSS 22 (IBM Corp., NY). Level of significance was set at $p<0.05$.

\section{Results}

\section{Selection of articles}

The preliminary database search, using the previously mentioned keyword combination, yielded 16023 abstracts throughout all three databases. Upon reading the titles and applying the inclusion and exclusion criteria, 1388 articles were retained for further selection. After reading the abstract, 515 articles remained. Finally, after a careful reading, 65 articles fulfilled the inclusion and exclusion criteria and were selected for further analysis (Figure 1). Table 1 outlines the main methodological aspects of these selected articles.

\section{Participant characteristics}

The main participant characteristics of the 65 selected articles are outlined in Table 1.

\section{Article data quality}

The Level of Evidence score attributed to each article was in agreement between reviewers. The mean Level of Evidence for all articles was $11.8 \pm 1.8$, with scores ranging from 6 to 14 . The Level of Evidence scores attributed to the 65 articles are outlined in Table 1.

\section{Parameters for gait analysis}

Table 2 indicates that parameters of various types were measured and counted in the selected articles. Parameters from power, work and/or torque were recorded 269 times,
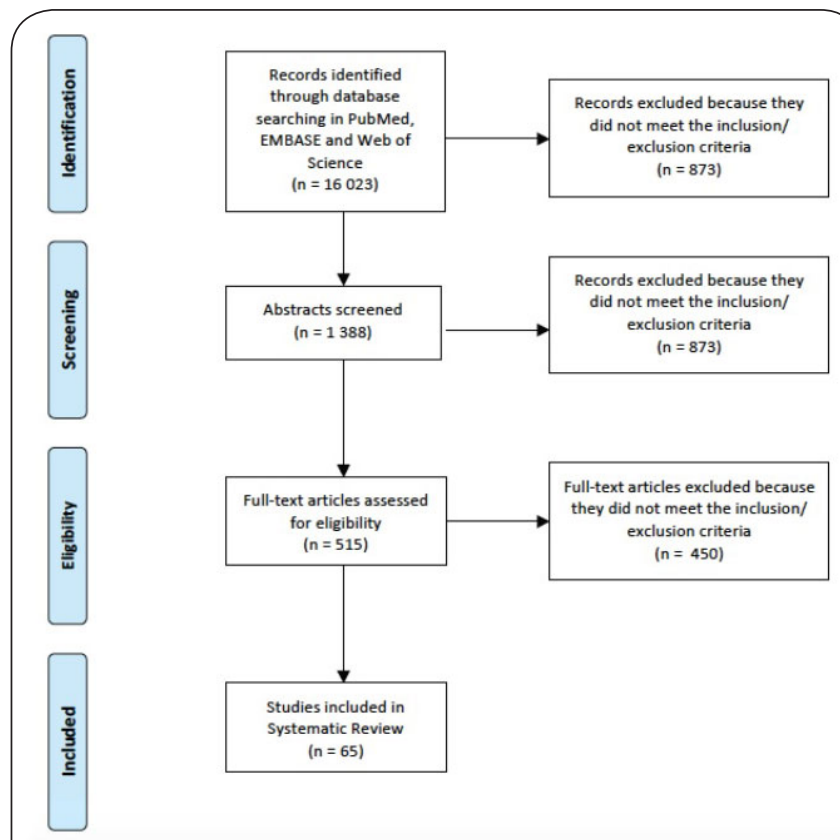

Figure 1. Article selection flowchart.

Flowchart as per PRISMA guidelines [19] summarizing the procedure for the selection of articles after the interrogation of three databases. All articles were retained or dismissed for analysis by the application of the inclusion and exclusion criteria (see methods). First, the articles were retained or dismissed on the basis of the article titles. A second step consisted of the reading of the article abstracts. Finally, all retained articles were read and a final selection was made.

spatio-temporal parameters were recorded (256 times), joint angles (177), moments (115) and force (115). A total of 1097 parameters were counted in 65 articles.

All measured biomechanical parameters in the selected articles are outlined in Table 2 . The parameter most often measured and/or calculated was the walking velocity (50 times) followed by cadence ( 30 times), stride length ( 23 times) and step length (21 times).

\section{Parameter summation}

As stated, a summation of parameters was carried out (results outlined in Table 3 ) and the results show that the hip power is the most often measured biomechanical parameter (66 times) followed by the knee power ( 61 times), walking velocity (50 times) and the ankle angle (47 times).

Also outlined in Table 3 is the number of different articles measuring summarized single parameters. Spatio-temporal parameters were measured in 59 of the 65 articles, angles by 29 different articles and forces in 16 articles. When considering summarized single parameters, walking velocity was measured in 50 different articles and stride length and cadence were measured in 36 and 35 different articles, respectively.

The calculation to account for both frequency of measurement and number of articles was carried out with the highest 
Roberts et al. Physical Therapy and Rehabilitation 2017,

Table 1. Methodological aspects of selected articles.

\begin{tabular}{|c|c|c|c|c|}
\hline Reference & $\begin{array}{l}\text { Number \& Sex of } \\
\text { participants }\end{array}$ & Age of participants & Main Objectives & Level of Evidence \\
\hline [20] & 30 (15 F: $15 \mathrm{M})$ & $20-29$ & $\begin{array}{l}\text { Basic gait data on groups of healthy young adult Kuwaitis of } \\
\text { both genders was collected to determine if they duplicated the } \\
\text { data published in the Swedish study. }\end{array}$ & 10 \\
\hline$[21]$ & $19(19 \mathrm{M})$ & $25.3(4.1)$ & $\begin{array}{l}\text { To determine, over two consecutive strides, if the right and } \\
\text { left lower limbs developed similar power patterns and if their } \\
\text { associated mechanical energies were equal or not in all } 3 \text { planes } \\
\text { of motion. }\end{array}$ & 14 \\
\hline$[22]$ & 17 (8M: 9F) & $27.5(5.3)$ & $\begin{array}{l}\text { To compare overground and treadmill ambulation for possible } \\
\text { differences in gait temporal variables and leg joint kinematics. }\end{array}$ & 12 \\
\hline [23] & $20(8 \mathrm{M}: 12 \mathrm{~F})$ & $37-62$ & $\begin{array}{l}\text { To evaluate the time-varying behavior, the test-retest reliability } \\
\text { and the concurrent validity of lateral trunk lean and toe-out } \\
\text { angles during prolonged walking in healthy adults. }\end{array}$ & 12 \\
\hline$[24]$ & $11(11 \mathrm{M})$ & $28.3(12.4)$ & $\begin{array}{l}\text { An examination of the angular momenta of healthy adult males } \\
\text { walking at three speeds; } 0.7,1.0 \text {, and } 1.3 \text { times their self-selected } \\
\text { comfortable walking speed. }\end{array}$ & 11 \\
\hline$[25]$ & $10(3 \mathrm{~F}: 7 \mathrm{M})$ & $27.5 ; 20-33$ & $\begin{array}{l}\text { To confirm the hypothesis that stride duration variability } \\
\text { exhibits long-range autocorrelations among young healthy } \\
\text { subjects walking on level ground, by using an integrated } \\
\text { approach that combines distinct methods in order to increase } \\
\text { the level of confidence. Also, to determine whether the treadmill } \\
\text { disrupts long-range autocorrelations present in stride duration } \\
\text { variability and to determine if the outcomes obtained from the } \\
\text { treadmill were reproducible across two different testing days. }\end{array}$ & 11 \\
\hline$[26]$ & $6(4 \mathrm{M}: 2 \mathrm{~F})$ & $25-45$ & $\begin{array}{l}\text { To improve the understanding of how the central nervous } \\
\text { system (CNS) chooses gait parameters for the modulation of } \\
\text { velocity by proposing a method for characterizing gait strategies } \\
\text { from step frequency and step length analysis. }\end{array}$ & 10 \\
\hline [27] & 30 (15F: 15M) & $23.6(2.7)$ & $\begin{array}{l}\text { To define the walking speed and gender effects on the center of } \\
\text { pressure (COP) pathway. }\end{array}$ & 11 \\
\hline$[28]$ & 98 (51 M: $47 \mathrm{~F})$ & $23.5(2.7) ; 22.9(4.9)$ & $\begin{array}{l}\text { The research hypothesis was that healthy adults would walk } \\
\text { differently according to their gender when walking barefoot at } \\
\text { their comfortable speed. }\end{array}$ & 14 \\
\hline [29] & 14 (8M: 6F) & $22.5(3) ; 23.8(4.1)$ & $\begin{array}{l}\text { To determine if there are changes in temporal gait parameters } \\
\text { with a focus on the pelvis when comparing overground and } \\
\text { treadmill ambulation, and to assess the effect of sex. }\end{array}$ & 11 \\
\hline$[30]$ & $\begin{array}{l}30 \text { (6 groups of } 5) \\
(15 \mathrm{M}: 15 \mathrm{~F})\end{array}$ & $\begin{array}{l}20-30 \\
31-45 \\
46-60\end{array}$ & $\begin{array}{l}\text { To investigate the effects of age, gender and walking speed on } \\
\text { different gait performance measures including joint motion, } \\
\text { ground reaction forces (GRF), electromyography (EMG), heart } \\
\text { rate (HR), and perceived exertion during walking at different } \\
\text { percentage of preferred walking speed (PPWS). }\end{array}$ & 12 \\
\hline$[31]$ & $8(6 \mathrm{M}: 2 \mathrm{~F})$ & $22-30$ & $\begin{array}{l}\text { To examine trunk, neck and head movements to determine a } \\
\text { mechanism for upper body stabilization during walking. }\end{array}$ & 12 \\
\hline$[32]$ & 10 (5M: 5F) & $27.10(3.25)$ & $\begin{array}{l}\text { To demonstrate that the processes responsible for maintaining } \\
\text { local dynamic stability of walking act across multiple consecu- } \\
\text { tive strides of gait. }\end{array}$ & 11 \\
\hline$[33]$ & 14 (4M: 10F) & $30-55$ & $\begin{array}{l}\text { To analyze foot and ankle kinematics from gait recordings of } \\
\text { healthy subjects walking at comfortable and slower speeds. }\end{array}$ & 11 \\
\hline$[34]$ & 10 (7M: 3F) & $23(2)$ & $\begin{array}{l}\text { To analyze the } 3 \mathrm{D} \text { angle between the joint moment and the joint } \\
\text { angular velocity vectors at the ankle, knee and hip during the } \\
\text { gait cycle and to investigate if these joints are predominantly } \\
\text { driven or stabilized. }\end{array}$ & 11 \\
\hline$[35]$ & 46 (32M: 14F) & -- & $\begin{array}{l}\text { Velocity, stride length and stride frequency were treated as in- } \\
\text { dependent variables in relation to each other in a graphic form } \\
\text { to see how they interact in gait. To achieve this, a Velocity Field } \\
\text { Diagram (VFD) was described. }\end{array}$ & 6 \\
\hline$[36]$ & $9(9 \mathrm{M})$ & $28.5(5)$ & $\begin{array}{l}\text { To characterize the basic features of the moment-angle curves in } \\
\text { normal walking at different velocities. }\end{array}$ & 12 \\
\hline
\end{tabular}


Roberts et al. Physical Therapy and Rehabilitation 2017, http://www.hoajonline.com/journals/pdf/2055-2386-4-6.pdf

\begin{tabular}{|c|c|c|c|c|}
\hline [37] & 39 (21M: 18F) & $\begin{array}{l}27(4.2) \\
22.9(4.1)\end{array}$ & $\begin{array}{l}\text { To characterize and compare the dynamic joint stiffness (DJS) of } \\
\text { the ankle in the sagittal plane during natural cadence walking in } \\
\text { both genders. }\end{array}$ & 12 \\
\hline [38] & $10(10 \mathrm{M})$ & $23.3(2.4)$ & $\begin{array}{l}\text { To investigate the variability and symmetry of ground reaction } \\
\text { force (GRF) measurements during walking, using time and } \\
\text { frequency domain analysis. }\end{array}$ & 13 \\
\hline [39] & $16(16 \mathrm{M})$ & $22.8(1.6)$ & $\begin{array}{l}\text { To demonstrate that data from a video-based system could } \\
\text { be used to estimate the net effect of the external forces during } \\
\text { gait, to determine the contribution of the trunk and upper and } \\
\text { lower limbs using their accelerated body masses, and to test the } \\
\text { hypothesis that the thigh mainly assumed lower limb propulsion } \\
\text { during able-bodied locomotion. }\end{array}$ & 14 \\
\hline$[40]$ & $20(20 \mathrm{M})$ & 23.8 (2.2.) & $\begin{array}{l}\text { To investigate the changes in horizontal velocity which are } \\
\text { known to influence many biomechanical characteristics of } \\
\text { human locomotion, with respect to the interlimb symmetry of } \\
\text { walking in a normal population. }\end{array}$ & 14 \\
\hline$[41]$ & 14 (8M: 6F) & $19-56$ & $\begin{array}{l}\text { 1) To determine whether asymmetries exist between limbs of } \\
\text { healthy individuals during gait and 2) to examine the rela- } \\
\text { tionship between lower extremity lateral dominance and any } \\
\text { observed differences. }\end{array}$ & 12 \\
\hline$[42]$ & $10(10 \mathrm{M})$ & $18-29$ & $\begin{array}{l}\text { 1) To determine whether long-range correlations in gait extend } \\
\text { over very long-time scales; } 2 \text { ) to define the conditions under } \\
\text { which such correlations may exist; and } 3 \text { ) to evaluate potential } \\
\text { mechanisms underlying this fractal property of gait. }\end{array}$ & 11 \\
\hline$[43]$ & $11(11 \mathrm{~F})$ & $27.4(4.0) ; 22-30$ & $\begin{array}{l}\text { To investigate the influence of walking speed on the amount and } \\
\text { structure of the stride-to-stride fluctuations of the gait cycle. }\end{array}$ & 9 \\
\hline$[44]$ & 13 (7M: 6F) & $23.3(3.0)$ & $\begin{array}{l}\text { To examine how gait speed influences healthy individual's lower } \\
\text { trunk motion during overground walking and to assess if Prin- } \\
\text { cipal Component Analysis (PCA) can be used to gain further } \\
\text { insight into postural responses that occur at different walking } \\
\text { speeds. }\end{array}$ & 13 \\
\hline$[45]$ & 10 & $23(4)$ & $\begin{array}{l}\text { To investigate the relationship between oscillatory dynamics of } \\
\text { the head and trunk in each plane of motion during walking. }\end{array}$ & 13 \\
\hline$[46]$ & 68 (32M: 36F) & $34(11)$ & $\begin{array}{l}\text { To examine the changes, if any that occur in peak lower } \\
\text { extremity net joint moments while walking in industry recom- } \\
\text { mended athletic footwear. }\end{array}$ & 12 \\
\hline$[47]$ & $110(57 \mathrm{~F}: 53 \mathrm{M})$ & $\begin{array}{l}29.1(8.9) \\
28.3(5.04)\end{array}$ & $\begin{array}{l}\text { To determine if knee joint torques, which are likely relevant to } \\
\text { the development and, possibly, progression of knee osteoar- } \\
\text { thritis, are equivalent between genders during natural, barefoot } \\
\text { walking. }\end{array}$ & 14 \\
\hline$[48]$ & 30 (17M: 13F) & $24.6(4.0)$ & $\begin{array}{l}\text { To evaluate the effect of pelvic rotation, originally described as } \\
\text { the first determinant of gait, on reducing the vertical displace- } \\
\text { ment of the center of mass (COM) during comfortable speed } \\
\text { walking. }\end{array}$ & 13 \\
\hline [49] & 20 (10M: 10F) & $27-56$ & $\begin{array}{l}\text { To determine three-dimensional foot and ankle kinematics, } \\
\text { using a three-segment foot model and to determine ground } \\
\text { reaction forces, temporal force factors and time-related factors } \\
\text { in normal subjects. }\end{array}$ & 12 \\
\hline$[50]$ & $25(25 \mathrm{M})$ & $26.2(5.2)$ & $\begin{array}{l}\text { To test if the lower limb joint and thoraco-lumbar moments are } \\
\text { similar in subjects who maintain an average natural forward or } \\
\text { backward trunk inclination during gait and verify if the lower } \\
\text { limbs are equally affected. }\end{array}$ & 12 \\
\hline$[51]$ & 16 (8M: 8F) & $18-28$ & $\begin{array}{l}\text { To study the familiarization time required for reliable sagittal- } \\
\text { plane knee kinematics and temporal-distance gait measure- } \\
\text { ments to be obtained from treadmill walking and whether knee } \\
\text { kinematics and temporal-distance gait measurements obtained } \\
\text { from familiarized treadmill walking can be generalized to over- } \\
\text { ground walking. }\end{array}$ & 14 \\
\hline
\end{tabular}


Roberts et al. Physical Therapy and Rehabilitation 2017,

\begin{tabular}{|c|c|c|c|c|}
\hline$[52]$ & 20 (5M: 15F) & $18-30$ & $\begin{array}{l}\text { To investigate the short-term relationships between footstep } \\
\text { variables during steady state, straight-line, over-ground walking } \\
\text { in healthy adults and to explore the extent to which the perfor- } \\
\text { mance of a step or stride is dependent on the performance of an } \\
\text { earlier step or stride in a sequence. }\end{array}$ & 12 \\
\hline$[53]$ & 10 (7M: 3F) & $26.9(5.7)$ & $\begin{array}{l}\text { To examine the effect of walking speed on center of mass } \\
\text { (COM) displacement in the medial-lateral (ML) and vertical } \\
\text { directions. }\end{array}$ & 13 \\
\hline$[54]$ & $10(6 \mathrm{M}: 4 \mathrm{~F})$ & $23(5)$ & $\begin{array}{l}\text { 1) Quantifying gait pseudo-periodicity using information } \\
\text { concerning a single stride; } 2 \text { ) investigating the effects of walking } \\
\text { pathway length on gait periodicity; } 3 \text { ) investigating separately } \\
\text { the periodicity of the upper and lower body part movements; } 4 \text { ) } \\
\text { verifying the validity of foot-floor contact events as markers of } \\
\text { the gait cycle period. }\end{array}$ & 12 \\
\hline$[55]$ & $8(4 \mathrm{M}: 4 \mathrm{~F})$ & $24-38$ & $\begin{array}{l}\text { To determine if walking at the predicted frequency produced } \\
\text { greater shock attenuation through the body when compared } \\
\text { with other frequencies at the same walking speed and to assess } \\
\text { the role played by the individual segments in attenuating shock } \\
\text { under different frequency-stride length combinations at a con- } \\
\text { stant speed. }\end{array}$ & 12 \\
\hline$[56]$ & 26 (13M: 13F) & $18-35$ & $\begin{array}{l}\text { (1) To compare the kinematics of treadmill gait to overground } \\
\text { gait obtained in laboratory, comparing the present findings to } \\
\text { those previously reported and (2) to quantify any kinetic dif- } \\
\text { ferences between overground and treadmill gait, including, for } \\
\text { the first time an analysis of the joint moments and powers of } \\
\text { treadmill gait. }\end{array}$ & 7 \\
\hline$[57]$ & 48 (10M: 38F) & $23-62$ & $\begin{array}{l}\text { To simultaneously statistically test whether the three factors } \\
\text { gender, age and walking speed significantly affect kinematic gait } \\
\text { data in a reference population. }\end{array}$ & 14 \\
\hline$[58]$ & 22 (9M: 13F) & $35-55$ & $\begin{array}{l}\text { To determine if the variability in the characteristics of the } \\
\text { net external hip adduction moment can be explained by the } \\
\text { strength of the hip abductor musculature, subject anthropomet- } \\
\text { rics, gait velocity and the corresponding characteristics of the } \\
\text { gluteus medius electromyogram captured during gait in healthy } \\
\text { individuals. }\end{array}$ & 12 \\
\hline [59] & 32 (20M: $12 \mathrm{~F})$ & $\begin{array}{l}24.9(2): \\
24.1(1.6)\end{array}$ & $\begin{array}{l}\text { Gait analysis was conducted on Korean subjects in their } 20 \mathrm{~s} \text { and } \\
\text { these gait characteristics were compared to those reported in } \\
\text { previously published studies conducted in Western countries. }\end{array}$ & 13 \\
\hline [60] & $20(20 \mathrm{M})$ & $25.3(4.1)$ & $\begin{array}{l}\text { To test the hypothesis that limb propulsion is mainly associated } \\
\text { with the interaction of a number of muscle power bursts devel- } \\
\text { oped throughout the stance phase and that the control actions } \\
\text { are mainly achieved by the contralateral limb through different } \\
\text { power-burst interactions. }\end{array}$ & 12 \\
\hline [61] & $19(19 \mathrm{M})$ & $26.2(3.2)$ & $\begin{array}{l}\text { To test the hypothesis that the trailing limb contributes mainly } \\
\text { to forward progression, whereas the trailing limb provides con- } \\
\text { trol and propels the lower limb to a lesser extent. }\end{array}$ & 14 \\
\hline [62] & $20(20 \mathrm{M})$ & $25.3(4.1)$ & $\begin{array}{l}\text { (a) To identify the main functions of the ankle and hip muscle } \\
\text { moments and their contribution to support and propulsion } \\
\text { tasks, and (b) to illustrate the interaction between ankle and hip } \\
\text { moment activities. }\end{array}$ & 14 \\
\hline [63] & $19(19 \mathrm{M})$ & $25.3(4.1)$ & $\begin{array}{l}\text { To demonstrate that the ankle frontal muscle power absorption } \\
\text { and generation at push-off are related to the foot's initial posi- } \\
\text { tion at heel-strike with respect to the body center of mass. }\end{array}$ & 13 \\
\hline$[64]$ & 20 (10M: 10F) & $24(3)$ & $\begin{array}{l}\text { To compare bilateral ground reaction force impulses to evaluate } \\
\text { functional asymmetry as an explanation for gait asymmetries. }\end{array}$ & 13 \\
\hline [65] & 25 (8M: $17 \mathrm{~F})$ & $19-32$ & $\begin{array}{l}\text { To report the reproducibility of the invariant walk ratio in re- } \\
\text { peated trials involving young healthy adults walking at a variety } \\
\text { of speeds. }\end{array}$ & 12 \\
\hline
\end{tabular}


Roberts et al. Physical Therapy and Rehabilitation 2017,

\begin{tabular}{|c|c|c|c|c|}
\hline$[66]$ & 22 (10M: 12F) & $\begin{array}{l}25.9(4.1): \\
20.6(1.4)\end{array}$ & $\begin{array}{l}\text { To examine whether there is an optimal walking speed with } \\
\text { minimum intrasubject variability in step length and step width } \\
\text { during free walk and whether there is an optimal step rate with } \\
\text { minimum step length variability during walking with imposed } \\
\text { step rates. }\end{array}$ & 12 \\
\hline [67] & 28 (14M: 14F) & $20-34$ & $\begin{array}{l}\text { To test the applicability a control scheme to the unconstrained } \\
\text { portion of the gait cycle- the swing phase. }\end{array}$ & 11 \\
\hline$[68]$ & 40 (20M: 20F) & $\begin{array}{l}24.1(3.1): \\
22.5(3.2)\end{array}$ & $\begin{array}{l}\text { To determine the kinematic variability of the lower extreity } \\
\text { joints using methods from the mathematical chaos theory in } \\
\text { a normal walking environment in conjunction with a large } \\
\text { population of healthy young adults and to test the hypothesis } \\
\text { that variability characteristics are different between joints and } \\
\text { to further investigate differences between male and female and } \\
\text { right and left subgroups. }\end{array}$ & 13 \\
\hline [69] & 10 (5M: 5F) & $19-34$ & $\begin{array}{l}\text { 1) To introduce the knee moment arm length as a measure to } \\
\text { evaluate knee pre- and postoperatively; (2) to determine the } \\
\text { variability in trials done minutes apart and trials done days } \\
\text { apart; ( } 3 \text { ) to present some normative data for healthy subjects } \\
\text { for use as reference values in assessment of patients with knee } \\
\text { deformities; and (4) to determine the variability in the hip, knee } \\
\text { and ankle moments in the frontal and sagittal planes, in trials } \\
\text { done minutes apart and days apart. }\end{array}$ & 11 \\
\hline$[70]$ & $\begin{array}{l}16 \\
\text { (slow:3M: 5F) } \\
\text { (fast: } 3 \mathrm{M}: 5 \mathrm{~F})\end{array}$ & $\begin{array}{l}\text { Slow: } 20.74 \\
\text { Fast: } 19.75\end{array}$ & $\begin{array}{l}\text { To determine the familiarization period required to obtain con- } \\
\text { sistent measurements of the angular movements of the lumbar } \\
\text { spine and pelvis during treadmill walking. }\end{array}$ & 13 \\
\hline$[71]$ & $\begin{array}{l}27 \\
\text { (slow: } 7 \mathrm{M}: 6 \mathrm{~F}) \\
\text { (fast: } 5 \mathrm{M}: 9 \mathrm{~F})\end{array}$ & $\begin{array}{l}\text { Slow: } 23.5(5.1) \\
\text { Fast: } 20.6(2.8)\end{array}$ & $\begin{array}{l}\text { To study the effect of walking at a self-selected and at a slower } \\
\text { speed on the angular movements of the pelvis and lumbar spine } \\
\text { and how interpretation of speed effects on lumbar spine move- } \\
\text { ments was influenced by frame of reference, either relative to the } \\
\text { pelvis or relative to a global reference frame. }\end{array}$ & 8 \\
\hline$[72]$ & 14 (7M: 7F) & $46(13.3)$ & $\begin{array}{l}\text { To employ an analytical model to estimate the effects of walking } \\
\text { cadence and laterality on the positive and negative mechani- } \\
\text { cal work performed by the hip, knee and ankle muscles in the } \\
\text { sagittal plane. }\end{array}$ & 12 \\
\hline$[73]$ & $8(3 \mathrm{M}: 5 \mathrm{~F})$ & $23-34$ & $\begin{array}{l}\text { To measure the mechanical energy changes of the center of } \\
\text { gravity (CG) of the body in forward, lateral and vertical direc- } \\
\text { tion during normal level walking at intermediate and low } \\
\text { speeds. }\end{array}$ & 11 \\
\hline$[74]$ & 18 (9M: 9F) & $35.9(10)$ & $\begin{array}{l}\text { To test the 2D PL (power law) compliance of motion of the } \\
\text { center of mass (CM) within the step, as a premise to further 3D } \\
\text { modeling, so far applied to upper limb motion. }\end{array}$ & 11 \\
\hline$[75]$ & 62 (21M: $41 \mathrm{~F})$ & $41.4(11.0)$ & $\begin{array}{l}\text { To investigate if the detailed pressure data of the footprints of } \\
\text { normal gait add essential information to the spatio-temporal } \\
\text { variables of gait. }\end{array}$ & 6 \\
\hline$[76]$ & $19(19 M)$ & $25.3(4.1)$ & $\begin{array}{l}\text { To determine if more than one gait pattern exists in able-bodied } \\
\text { young men, by analyzing the dissimilarities in the three-dimen- } \\
\text { sional (3-D) muscle powers developed at the joints of the right } \\
\text { lower limb. }\end{array}$ & 14 \\
\hline [77] & $9(9 M)$ & $28.7(4.4)$ & $\begin{array}{l}\text { To determine the differences between angular oscillation curves } \\
\text { of the lumbar spine and pelvis during walkway and treadmill } \\
\text { ambulation. }\end{array}$ & 14 \\
\hline [78] & 15 (4M: 11F) & $25.5(4.5)$ & $\begin{array}{l}\text { To determine if limb dominance affects the vertical ground reac- } \\
\text { tion force and center of pressure (COP) during able-bodied gait. }\end{array}$ & 9 \\
\hline [79] & 10 (5M: 5F) & $24.3(4.0)$ & $\begin{array}{l}\text { Sole-floor reaction forces were measured from five anatomically } \\
\text { discrete points in the human sole during locomotion on the } \\
\text { treadmill and on the laboratory floor. }\end{array}$ & 14 \\
\hline$[80]$ & 24 (11M: $13 \mathrm{~F})$ & $27(7)$ & $\begin{array}{l}\text { To compare vertical ground reaction forces walking overground } \\
\text { with vertical foot-belt forces for treadmill gait. }\end{array}$ & 10 \\
\hline$[81]$ & 20 (9M: 11F) & $24(4)$ & $\begin{array}{l}\text { To investigate the contribution of passive mechanisms to lower } \\
\text { extremity joint kinetics in normal walking at slow, comfortable } \\
\text { and fast speeds. }\end{array}$ & 12 \\
\hline
\end{tabular}


Roberts et al. Physical Therapy and Rehabilitation 2017,

\begin{tabular}{|c|c|c|c|c|}
\hline$[82]$ & 12 & $28.5(3.3)$ & $\begin{array}{l}\text { To investigate whether multiple short bouts of gait can be used } \\
\text { for the valid and reliable assessment of variability and local } \\
\text { dynamic stability, and how many bouts are required for their } \\
\text { reliable estimation. }\end{array}$ & 11 \\
\hline$[83]$ & 21 (10M: 11F) & $26.9(4.5)$ & $\begin{array}{l}\text { To assess the validity of the anatomical landmark data derived } \\
\text { from the Kinect's skeleton tracking algorithm for examining } \\
\text { the spatiotemporal characteristics of gait in young, healthy } \\
\text { individuals. }\end{array}$ & 11 \\
\hline$[84]$ & $10(10 \mathrm{M})$ & $28.8(8.3)$ & $\begin{array}{l}\text { To demonstrate how vector field statistics can be used to more } \\
\text { objectively analyse CoP trajectories. }\end{array}$ & 10 \\
\hline
\end{tabular}

Methodological aspects of all selected articles. The above chart depicts the reference, number of participants, sex of participants (M for male: $\mathrm{F}$ for female), the participant age (mean, standard deviation in parentheses and range separated by a hyphen), as well as the main objectives of the study and the Level of Evidence score attributed to each article (on a possible 14 total points). All available information concerning participant characteristics was provided. If the articles reported participant age and sex characteristics per group (i.e. fast and slow walking group), the information is provided as such.

Table 2. Measured biomechanical parameters.

\begin{tabular}{|c|c|c|c|c|c|}
\hline \multicolumn{6}{|c|}{ POWER, WORK \& TORQUE (269) } \\
\hline Parameter & Total & Articles & Parameter & Total & Articles \\
\hline Sagittal hip power peak 1 & 5 & {$[60,61,72,76,81]$} & Sagittal hip power peak 2 & 2 & {$[60,61]$} \\
\hline Sagittal hip power peak 2 & 5 & {$[60,61,72,76,81]$} & Sagittal hip power peak 3 & 2 & {$[60,61]$} \\
\hline Sagittal hip power peak 3 & 5 & {$[60,61,72,76,81]$} & Frontal hip power peak 1 & 2 & {$[60,61]$} \\
\hline Sagittal knee power peak 1 & 5 & {$[60,61,72,76,81]$} & Frontal hip power peak 2 & 2 & {$[60,61]$} \\
\hline Sagittal knee power peak 2 & 5 & {$[60,61,72,76,81]$} & Frontal hip power peak 4 & 2 & {$[60,61]$} \\
\hline Sagittal knee power peak 3 & 5 & {$[60,61,72,76,81]$} & Transverse hip energy peak 1 & 2 & {$[60,61]$} \\
\hline Sagittal ankle power peak 1 & 5 & {$[60,61,72,76,81]$} & Transverse hip energy peak 2 & 2 & {$[60,61]$} \\
\hline Sagittal ankle power peak 2 & 5 & {$[60,61,72,76,81]$} & Transverse hip energy peak 3 & 2 & {$[60,61]$} \\
\hline Frontal ankle power peak 2 & 4 & {$[60,61,63,76]$,} & Sagittal knee energy peak 1 & 2 & {$[60,61]$} \\
\hline Frontal hip power peak 1 & 3 & {$[60,61,76]$} & Sagittal knee energy peak 2 & 2 & {$[60,61]$} \\
\hline Frontal hip power peak 2 & 3 & {$[60,61,76]$} & Sagittal knee energy peak 3 & 2 & {$[60,61]$} \\
\hline Frontal hip power peak 3 & 3 & {$[60,61,76]$} & Frontal knee energy peak 1 & 2 & {$[60,61]$} \\
\hline Transverse hip power peak 1 & 3 & {$[60,61,76]$} & Frontal knee energy peak 2 & 2 & {$[60,61]$} \\
\hline Transverse hip power peak 2 & 3 & {$[[60,61,76]$} & Transverse knee energy peak 1 & 2 & {$[60,61]$} \\
\hline Transverse hip power peak 3 & 3 & {$[60,61,76]$} & Transverse knee energy peak 2 & 2 & {$[60,61]$} \\
\hline Sagittal knee power peak 4 & 3 & {$[72,76,81]$} & Transverse knee energy peak 3 & 2 & {$[60,61]$} \\
\hline Frontal knee power peak 1 & 3 & {$[60,61,76]$} & Sagittal ankle energy peak 1 & 2 & {$[60,61]$} \\
\hline Frontal knee power peak 2 & 3 & {$[60,61,76]$} & Sagittal ankle energy peak 2 & 2 & {$[60,61]$} \\
\hline $\begin{array}{l}\text { Transverse knee power peak } \\
1\end{array}$ & 3 & {$[60,61,76]$} & Frontal ankle energy peak 1 & 2 & {$[60,61]$} \\
\hline $\begin{array}{l}\text { Transverse knee power peak } \\
2\end{array}$ & 3 & {$[60,61,76]$} & Frontal ankle energy peak 2 & 2 & {$[60,61]$} \\
\hline $\begin{array}{l}\text { Transverse knee power peak } \\
3\end{array}$ & 3 & {$[60,61,76]$} & Sagittal plane knee power & 2 & {$[21,81]$} \\
\hline Frontal ankle power peak 1 & 3 & {$[60,61,76]$} & Sagittal plane hip power & 2 & {$[21,81]$} \\
\hline Frontal hip power peak 3 & 3 & {$[60,61,63]$} & Sagittal plane ankle power & 2 & {$[21,81]$} \\
\hline Frontal hip power peak 4 & 2 & {$[60,61]$} & Frontal plane ankle power & 2 & {$[21,63]$} \\
\hline Sagittal hip power peak 1 & 2 & {$[60,61]$} & & & \\
\hline \multicolumn{6}{|c|}{ SPATIO-TEMPORAL PARAMETERS (256) } \\
\hline Parameter & Total & Articles & Parameter & Total & Articles \\
\hline Walking velocity & 50 & $\begin{array}{l}{[20,21,27-30,32,33,40,42-} \\
46,48,50-53,55-61,60- \\
67,61,76,81,71- \\
77,79,80,81,83,84]\end{array}$ & Stride width & 4 & {$[28,33,53,59]$} \\
\hline
\end{tabular}


Roberts et al. Physical Therapy and Rehabilitation 2017,

http://www.hoajonline.com/journals/pdf/2055-2386-4-6.pdf

\begin{tabular}{|c|c|c|c|c|c|}
\hline Cadence & 30 & $\begin{array}{l}{[20,21,22,37,24,26-30,49-56,59,} \\
60,61,72,75,76,79,63,65,66 \\
67,80]\end{array}$ & Swing time & 4 & {$[22,24,59,75]$} \\
\hline Stride length & 23 & $\begin{array}{l}{[22,21,35,36,24,28,32,33,43,50} \\
51,53,56,59,60,61,72,75,76,63,6 \\
7,80,83]\end{array}$ & $\%$ Stance time & 3 & {$[21,28,38]$} \\
\hline Step length & 21 & $\begin{array}{l}{[20,21,26,33,41,43,44,48,52,53,5} \\
4,59,60,61,73,75,76,65,66,67,83]\end{array}$ & Step time & 4 & {$[20,41,75,83]$} \\
\hline Stance time & 12 & $\begin{array}{l}{[38,24,29,39,40,41,49,59,60,61} \\
75,79]\end{array}$ & Time of heelstrike & 3 & {$[25,31,39]$} \\
\hline Gait cycle (\%) & 10 & {$[34,28,29,44,46,47,50,54,57,59]$} & Time of toe-off & 3 & {$[31,33,39]$} \\
\hline Stride time & 12 & $\begin{array}{l}{[25,22,35,29,32,33,44,51,54,56,} \\
80,83]\end{array}$ & Breaking phase & 2 & {$[60,61]$} \\
\hline Double support time & 7 & {$[24,31,33,52,60,61,75]$} & Stride interval & 2 & {$[42,43]$} \\
\hline \% Stance phase & 6 & {$[33,49,50,63,75,76]$} & Stride frequency & 2 & {$[32,35]$} \\
\hline Gait cycle time & 5 & {$[41,49,75,67,77]$} & Terminal double support time & 2 & {$[60,61]$} \\
\hline \% Double support & 4 & {$[21,28,56,75]$} & Step width & 2 & {$[54,66]$} \\
\hline \multicolumn{6}{|l|}{ ANGLES (177) } \\
\hline Parameter & Total & Articles & Parameter & Total & Articles \\
\hline $\begin{array}{l}\text { Maximum ankle sagittal } \\
\text { plane dorsiflexion }\end{array}$ & 4 & {$[30,41,49,56]$} & Maximum hip sagittal plane flexion & 2 & {$[30,56]$} \\
\hline $\begin{array}{l}\text { Maximum ankle sagittal } \\
\text { plane plantarflexion }\end{array}$ & 4 & {$[30,41,49,56]$} & $\begin{array}{l}\text { Maximum hip sagittal plane exten- } \\
\text { sion }\end{array}$ & 2 & {$[30,56]$} \\
\hline Hip sagittal angle & 3 & {$[22,81,67]$} & $\begin{array}{l}\text { Maximum knee sagittal plane exten- } \\
\text { sion }\end{array}$ & 2 & {$[41,56]$} \\
\hline Knee sagittal angle & 3 & {$[22,81,67]$} & Frontal plane ankle angular velocity & 2 & {$[21,63]$} \\
\hline Ankle sagittal angle & 3 & {$[22,81,67]$} & $\begin{array}{l}\text { Upward maximum pelvic obliquity } \\
\text { angle }\end{array}$ & 2 & {$[29,56]$} \\
\hline $\begin{array}{l}\text { Maximum knee sagittal } \\
\text { plane flexion }\end{array}$ & 3 & {$[30,41,56]$} & $\begin{array}{l}\text { Downward minimum pelvic obliq- } \\
\text { uity angle }\end{array}$ & 2 & {$[29,56]$} \\
\hline Foot progression angle & 2 & {$[57,58]$} & Max knee extension angle & 2 & {$[22,32]$} \\
\hline $\begin{array}{l}\text { Sagittal plane ankle angle } \\
\text { position }\end{array}$ & 2 & {$[36,49]$} & Pelvic rotation angle & 2 & {$[48,57]$} \\
\hline $\begin{array}{l}\text { Sagittal plane hip angle } \\
\text { position }\end{array}$ & 2 & {$[36,28]$} & & & \\
\hline \multicolumn{6}{|l|}{ MOMENTS (115) } \\
\hline Parameter & Total & Articles & Parameter & Total & Articles \\
\hline Sagittal plane hip moment & 6 & {$[21,36,46,50,81,60]$} & Peak knee flexion moment & 2 & {$[46,56]$} \\
\hline Sagittal plane ankle moment & 6 & {$[21,36,46,50,81,60]$} & Peak knee varus moment 1 & 2 & {$[46,56]$} \\
\hline Sagittal plane knee moment & 5 & {$[21,36,46,50,81]$} & $\begin{array}{l}\text { Peak knee external rotation } \\
\text { moment }\end{array}$ & 2 & {$[46,56]$} \\
\hline Peak hip extension moment & 4 & {$[46,50,56,60]$} & Peak knee internal rotation moment & 2 & {$[46,56]$} \\
\hline Peak hip flexion moment & 4 & {$[46,50,56,60]$} & Peak ankle eversion moment & 2 & {$[46,56]$} \\
\hline $\begin{array}{l}\text { Peak ankle dorsiflexion mo- } \\
\text { ment }\end{array}$ & 3 & {$[46,56,60]$} & $\begin{array}{l}\text { Peak ankle external rotation } \\
\text { moment }\end{array}$ & 2 & {$[46,56]$} \\
\hline $\begin{array}{l}\text { Peak ankle plantarflexion } \\
\text { moment }\end{array}$ & 3 & {$[50,56,60]$} & $\begin{array}{l}\text { Peak ankle internal rotation } \\
\text { moment }\end{array}$ & 2 & {$[46,56]$} \\
\hline Frontal plane ankle moment & 3 & {$[21,46,63]$} & Transverse plane knee moment & 2 & {$[21,46]$} \\
\hline $\begin{array}{l}\text { Peak knee extension moment } \\
1\end{array}$ & 2 & {$[50,56]$} & Frontal plane knee moment & 2 & {$[21,46]$} \\
\hline $\begin{array}{l}\text { Peak hip adduction mo- } \\
\text { ment } 1\end{array}$ & 2 & {$[46,56]$} & Transverse plane hip moment & 2 & {$[21,46]$} \\
\hline $\begin{array}{l}\text { Peak hip external rotation } \\
\text { moment }\end{array}$ & 2 & {$[46,56]$} & Frontal plane hip moment & 2 & {$[21,46]$} \\
\hline $\begin{array}{l}\text { Peak hip internal rotation } \\
\text { moment }\end{array}$ & 2 & {$[46,56]$} & Transverse plane ankle moment & 2 & {$[21,46]$} \\
\hline
\end{tabular}


Roberts et al. Physical Therapy and Rehabilitation 2017,

\begin{tabular}{|c|c|c|c|c|c|}
\hline \multicolumn{6}{|l|}{ FORCES (115) } \\
\hline Parameter & Total & Articles & Parameter & Total & Articles \\
\hline Fz1 & 8 & {$[38,30,40,43,46,49,78,80]$} & V1 (vertical maximum force) & 3 & {$[39,56,59]$} \\
\hline Fz3 & 8 & {$[38,30,40,43,46,49,78,80]$} & S1 (sagittal maximum force) & 3 & {$[39,56,59]$} \\
\hline Fz2 & 7 & {$[38,30,40,43,49,78,80]$} & T1 (maximum transverse force) & 3 & {$[39,56,59]$} \\
\hline Fy1 & 4 & {$[38,40,46,49]$} & Fx3 & 2 & {$[46,49]$} \\
\hline Fy2 & 4 & {$[38,40,46,49]$} & Time to Fx1 & 2 & {$[38,49]$} \\
\hline Time to Fz1 & 4 & {$[38,40,49,80]$} & S2 (sagittal minimum force) & 2 & {$[39,56]$} \\
\hline Time to Fz2 & 4 & {$[38,40,49,80]$} & S3 (sagittal maximum force) & 2 & {$[39,59]$} \\
\hline Time to Fz3 & 4 & {$[38,40,49,80]$} & T2 (minimum transverse force) & 2 & {$[39,56]$} \\
\hline Time to Fy1 & 3 & {$[38,40,49]$} & T4 (maximum transverse force) & 2 & {$[39,59]$} \\
\hline Time to Fy2 & 3 & {$[38,40,49]$} & Ground reaction forces AP & 2 & {$[64,74]$} \\
\hline \multicolumn{6}{|l|}{ SYMMETRY (25) } \\
\hline Parameter & Total & Articles & Parameter & Total & Articles \\
\hline Symmetry of Fz1 & 2 & {$[38,78]$} & Symmetry of Fz3 & 2 & {$[38,78]$} \\
\hline Symmetry of Fz2 & 2 & {$[38,78]$} & AP COP displacement & 2 & {$[78]$} \\
\hline \multicolumn{6}{|l|}{ CENTER OF MASS (22) } \\
\hline Parameter & Total & Articles & Parameter & Total & Articles \\
\hline COM displacement (vertical) & 3 & {$[48,53,74]$} & COM velocity (VT) & 2 & {$[53,74]$} \\
\hline COM displacement $(M / L)$ & 2 & {$[53,74]$} & COM velocity (M/L) & 2 & {$[53,74]$} \\
\hline COM displacement (A/P) & 2 & {$[63,74]$} & & & \\
\hline
\end{tabular}

LOCAL DYNAMIC STABILITY (19)

VARIABILITY (18)

COP (11)

OTHER (36)

Biomechanical parameters measured in included studies. This chart tabulates each biomechanical parameter as it was measured in the designated study. The reference measuring each given parameter is given, as well as the total for single parameters. The following parameters are grouped according to their type and a total of number of parameters measured per type is given in parentheses. Only parameters measured more than once are shown here. 
Table 3. Summation of parameters.

\begin{tabular}{|c|c|c|c|c|c|}
\hline \multicolumn{6}{|l|}{ POWER, WORK \& TORQUE (269) 13} \\
\hline Parameter & Total & Number of articles & Parameter & Total & Number of articles \\
\hline Hip power & 66 & 9 & Limb energy & 6 & 1 \\
\hline Knee power & 61 & 9 & Limb work & 6 & 1 \\
\hline Ankle power & 36 & 9 & Foot momentum & 6 & 1 \\
\hline Arm momentum & 12 & 1 & Shank momentum & 6 & 1 \\
\hline Energy & 8 & 1 & Thigh momentum & 6 & 1 \\
\hline Hip work & 6 & 1 & Knee torque & 5 & 2 \\
\hline Knee work & 6 & 1 & $\begin{array}{l}\text { Head \& neck mo- } \\
\text { mentum }\end{array}$ & 3 & 1 \\
\hline Ankle work & 6 & 1 & Torso momentum & 3 & 1 \\
\hline Hip energy & 6 & 1 & $\begin{array}{l}\text { Total body momen- } \\
\text { tum }\end{array}$ & 3 & 1 \\
\hline Knee energy & 6 & 1 & Hip torque & 1 & 1 \\
\hline Ankle power & 6 & 1 & Ankle torque & 1 & 1 \\
\hline \multicolumn{6}{|c|}{ SPATIO-TEMPORAL PARAMETERS (256) 59} \\
\hline Parameter & Total & Number of articles & Parameter & Total & Number of articles \\
\hline Walking velocity & 50 & 50 & Double support & 13 & 11 \\
\hline Stride length & 43 & 36 & Step width & 6 & 6 \\
\hline Gait cycle & 37 & 23 & Swing time & 6 & 5 \\
\hline Cadence & 37 & 35 & Single support & 2 & 2 \\
\hline Stance time & 22 & 19 & OTHER & 14 & 4 \\
\hline Stride time & 16 & 16 & & & \\
\hline \multicolumn{6}{|l|}{ ANGLES (177) 29} \\
\hline Parameter & Total & Number of articles & Parameter & Total & Number of articles \\
\hline Ankle angle & 47 & 17 & Lumbar angle & 7 & 1 \\
\hline Pelvis angle & 37 & 9 & Spine angle & 6 & 1 \\
\hline Hip angle & 30 & 13 & Neck angle & 2 & 1 \\
\hline Knee angle & 29 & 14 & Head angle & 2 & 1 \\
\hline Trunk angle & 8 & 4 & Sacrum angle & 1 & 1 \\
\hline Thorax angle & 7 & 1 & & & \\
\hline \multicolumn{6}{|l|}{ MOMENTS (115) 13} \\
\hline Parameter & Total & Number of articles & Parameter & Total & Number of articles \\
\hline L5 moment & 5 & 1 & Ankle moment & 35 & 12 \\
\hline Hip moment & 37 & 11 & Other & 8 & 2 \\
\hline Knee moment & 30 & 9 & & & \\
\hline \multicolumn{6}{|l|}{ FORCES (115) 16} \\
\hline Parameter & Total & Number of articles & Parameter & Total & Number of articles \\
\hline Vertical ground reaction force & 43 & 13 & $\begin{array}{l}\text { Lower limb ground } \\
\text { reaction forces }\end{array}$ & 3 & 1 \\
\hline $\begin{array}{l}\text { Anterior-posterior ground reaction } \\
\text { forces }\end{array}$ & 27 & 9 & $\begin{array}{l}\text { Upper limb ground } \\
\text { reaction forces }\end{array}$ & 3 & 1 \\
\hline Medial-lateral ground reaction forces & 22 & 6 & Other & 8 & 3 \\
\hline Head and trunk ground reaction forces & 3 & 1 & & & \\
\hline \multicolumn{6}{|l|}{ ACCELLERATION (52) 2} \\
\hline Parameter & Total & Number of articles & Parameter & Total & Number of articles \\
\hline Head velocity & 21 & 2 & Ankle velocity & 6 & 1 \\
\hline Trunk velocity & 13 & 1 & Knee velocity & 4 & 1 \\
\hline Shoulder velocity & 6 & 1 & Ankle velocity & 2 & 1 \\
\hline
\end{tabular}


Roberts et al. Physical Therapy and Rehabilitation 2017,

http://www.hoajonline.com/journals/pdf/2055-2386-4-6.pdf

\begin{tabular}{|c|c|c|c|c|c|}
\hline Parameter & Total & Number of articles & Parameter & Total & Number of articles \\
\hline Ground reaction symmetry & 12 & 3 & COP symmetry & 7 & 2 \\
\hline Spatio-temporal symmetry & 8 & 1 & & & \\
\hline \multicolumn{6}{|c|}{ CENTER OF MASS \& GRAVITY (22) 4} \\
\hline Parameter & Total & Number of articles & Parameter & Total & Number of articles \\
\hline Center of mass & 19 & 4 & Center of gravity & 3 & 1 \\
\hline \multicolumn{6}{|c|}{ LOCAL DYNAMIC STABILITY (19) 3} \\
\hline Parameter & Total & Number of articles & Parameter & Total & Number of articles \\
\hline Local Dynamic Stability & 18 & 3 & & & \\
\hline \multicolumn{6}{|l|}{ VARIABILITY (18) 3} \\
\hline Parameter & Total & Number of articles & Parameter & Total & Number of articles \\
\hline Coefficient of variation & 8 & 1 & Standard deviation & 7 & 1 \\
\hline \multicolumn{6}{|l|}{$\operatorname{COP}(\mathbf{1 1}) 3$} \\
\hline Parameter & Total & Number of articles & Parameter & Total & Number of articles \\
\hline COP velocity & 5 & 2 & COP position & 2 & 1 \\
\hline COP displacement & 3 & 1 & & & \\
\hline
\end{tabular}

Summation of all biomechanical parameters measured in included studies. This chart tabulates each parameter under a broader theme of parameters as well as the number of different articles which measure this summarized parameter. The total number of parameters measured per type is shown in parentheses beside the parameter type; the total number of different articles measuring a type of parameter is given beside these parentheses. The breakdown of the summation is not shown here. Only parameters measured more than once are shown.

frequency of measurement being the hip power (66 times) and the greatest number of articles being walking velocity (50 articles). Walking velocity obtained the highest score (0.879), followed by stride length (0.686), cadence (0.630), hip power (0.590) and knee power (0.552). The results of this score are presented in Table 4.

\section{Level of evidence score and Journal Impact Factor} It was sought whether a correlation existed between the article Journal Impact Factor (not shown) and the Level of Evidence score attributed to each article by means of a Spearman correlation. The result of this correlation is a very weak, negative and non-significant correlation $\left(r_{s}=-0.133\right.$, $p=0.105)$. The Impact Factor scores of 4 articles $[\mathbf{2 1 , 5 4 , 5 9 , 6 7 ]}$ were unavailable and were therefore excluded.

Frequency of parameters and Level of Evidence score When the frequency of the most often reported parameters was correlated with the mean Level of Evidence score of articles (not shown), via a Spearman correlation, a weak, negative and non-significant correlation was found $\left(r_{s}=-0.224, p=0.06\right)$.

\section{Discussion}

\section{Number of articles}

The current review was based on 65 articles. This number may appear small knowing that the review of Sagawa and colleagues [18] included 89 articles of a clinical population. The present study reflects the restrictiveness of our inclusion and exclusion criteria.
Type, single and summation of biomechanical parameters Types of biomechanical parameters

Considering types of parameters, it was found that power, work and energy parameters were measured most often (269 times): spatio-temporal parameters followed closely being measured 256 times. Joint angle parameters were measured 177 times, joint moment parameters were measured 115 times and forces were also measured 115 times. In comparison, the systematic review of Sagawa and colleagues [18], revealed that parameters of spatio-temporal type were measured 153 times, joint angles 78 times, platform parameters (i.e. ground reaction forces and center of pressure) 72 times, powers 64 times and joint moments 58 times. Thus, in general, the number of times a type of parameter was measured was less in the review of Sagawa and colleagues [18] than in the present review despite the fact that fewer articles were included for analysis in the current review.

These larger numbers are explained by the fact that both studies did not group parameters in the same manner; therefore, the number of parameters in relation to the total number of articles included in each study is different. Also, Sagawa and colleagues [18] carried out a summation of parameters in which both time sub-parameters and amplitude sub-parameters were grouped separately. For the purpose of our systematic review, it was thought more appropriate to group parameters accordingly, since all are yielded from one measure.

Omitting these disparities, it is possible to note that spatiotemporal parameters are of high relevance in both systematic 
Roberts et al. Physical Therapy and Rehabilitation 2017,

http://www.hoajonline.com/journals/pdf/2055-2386-4-6.pdf

Table 4. Relevance score.

\begin{tabular}{lccc}
\hline Parameter & Frequency & Number of articles & Relevance score \\
\hline POWER, WORK \& TORQUE & 66 & 9 & \\
Hip power & 61 & 9 & 0.590 \\
Knee power & 36 & 9 & 0.552 \\
Ankle power & & & 0.363 \\
\hline SPATIO-TEMPORAL PARAMETERS & 50 & 50 & 0.879 \\
\hline Walking velocity & 43 & 36 & 0.686 \\
Stride length & 37 & 35 & 0.510 \\
Cadence & 37 & 23 & 0.630 \\
Gait cycle & 22 & 19 & 0.357 \\
Stance time & & & 0.526 \\
\hline ANGLES & 47 & 17 & 0.370 \\
\hline Ankle angle & 37 & 9 & 0.360 \\
Pelvis angle & 29 & 14 & 0.357 \\
Knee angle & 30 & 13 & \\
Hip angle & & & 0.456 \\
\hline FORCES & 43 & 13 & \\
\hline Vertical ground reaction force & & & \\
\hline
\end{tabular}

This relevance score is calculated based on the frequency of measurement and the number of different articles measuring the given parameter, as described in the methods section. Only parameters which scored more than 0.300 are shown here.

reviews. As well, all most frequent types of parameters are the same, although they differ in number and order of relevance.

\section{Single parameters}

When looking at single parameters, the walking velocity $(50$ times), cadence (30 times), stride length ( 23 times) and step length ( 21 times) were those parameters most frequently measured. These results are in agreement with Sagawa and colleagues [18] who conclude the same parameters were most often measured: walking velocity, cadence, stride and step length. It is interesting to note that for these two different populations the same parameters would appear to be most relevant. This may be because parameters of spatio-temporal type have a certain ease of measurement in comparison to other parameters.

Despite the fact that in the current systematic review, power, work and energy parameters were the most frequently reported measures as a type of parameter, when considering single parameters, the most frequently measured were spatio-temporal. Interestingly, for power, work and energy type of parameters, no single parameter was reported more than 10 times and most parameters were measured only once. In fact, for these types of parameters, a given parameter can be measured at different instances of the gait cycle, in three different planes and for minima and maxima values, making the number of parameters somewhat inflated.

As well, more minima and maxima power values exist at the hip joint when compared to the ankle joint, for example. This may also explain some disparity in the frequency of measure- ment of some parameters, especially kinematic parameters of the lower limb joints.

\section{Summation of parameters}

After a summation of parameters, we observe that those parameters most frequently measured are hip power (66 times), knee power (61 times), walking velocity (50 times) and ankle angle (47 times). Following parameter summation, Sagawa and colleagues [18] concluded walking velocity (43 times), knee angle (31), knee moment (27 times) and hip power (26 times) were most often measured. These differences might reflect that the results are somewhat inflated and the angle, moment and power parameters need to be interpreted cautiously. Indeed, Sagawa and colleagues [18] did not group parameters in the same way as was done in the present review and the frequency obtained for angle, moment and power parameters are smaller. As well, for certain types of parameters (i.e. power, work and energy), the number of total parameters measured (i.e. 269 times) may also be inflated. Again, this may explain some disparity between the number of parameters measured with regards to the total number of articles.

Another explanation for these differences is the type of population studied. Indeed, their choice of clinical population implied the absence of the ankle joint which can explain the lack of ankle joint measures in their population with a transtibial amputation. In the healthy adult population, ankle joint measures were in the top four most relevant parameters after parameter summation.

Also interesting is that articles which measure hip mo- 
Roberts et al. Physical Therapy and Rehabilitation 2017,

ments, also tend to measure joint moments at the knee and ankle, as they are necessary in inverse dynamic calculations. As well, it is interesting to note that forces are needed in the calculation of moments and angular kinematics are needed for power calculations. Therefore, articles measuring powers, would also measure kinematics, forces and moments and this plays an important role when looking at frequency and relevance of parameters.

In addition to the frequency of measurement, it is also important to consider the number of different articles measuring a given parameter. Out of the total 65 articles included in our systematic review, spatio-temporal parameters were reported by 59 different articles, joint angles were reported by 29 articles, followed by forces ( 16 articles), joint moments (13 articles) and power, work and energy (13 articles). So for power, work and energy parameters (measured 269 times), the type of parameters which appear to have been measured most often, only 13 out of 65 articles measured these types of parameters. In comparison, spatio-temporal parameters (measured 256 times), were evaluated in 59 of the 65 articles.

As for the type of parameters discussed above, using the summarized parameters, the walking velocity remained the most often measured (50 articles out of 65 total articles) followed by cadence ( 35 articles), stride length ( 36 articles), gait cycle parameters ( 23 articles) and stance time ( 19 articles). However, when comparing these results to those of Sagawa and colleagues [18], we observe that a higher number of articles reported the most common parameters in our present study: walking velocity was measured only 43 times in 89 articles, cadence 19 times and step and stride length 19 times and 15 times, respectively. An important note must be made here that parameters were summarized differently by both reviews. The differences in the number of articles can, in large part, be explained by the choice of inclusion and exclusion criteria.

As shown by our results, both frequency of measurement and the number of different articles measuring a parameter are of importance when investigating the most relevant biomechanical parameters for gait analysis. The results of the score combining both these factors show that walking velocity, stride length and cadence appear to be most relevant.

\section{Level of Evidence score}

The mean Level of Evidence score for all articles was 11.8 \pm 1.8 out of 14 points. This mean score is high; one can argue that it almost reaches a ceiling effect. It is perhaps because the Level of Evidence was not discriminatory enough in the limits for scoring. This can also be due to high quality and soundly based studies. It is perhaps simpler to carry out quality experimentation in a healthy population since there may be less physical restrictions and/or needs as compared to other clinical populations. This may also be due to the inclusion/ exclusion criteria weeding out the lower quality articles. A Level of Evidence score with a wider array of possible scores would be needed.

\section{Relation between the Level of Evidence score and Journal Impact Factor}

The Level of Evidence score of articles were correlatedwith the Journal Impact Factor. The weak, negative and non-significant Spearman correlation found is in agreement with that of Sagawa and colleagues [18] who carried out this same analysis but with the Journal Impact Factors of the year of publication of their systematic review. It is possible to conclude that both Level of Evidence score and the Journal Impact Factor are not related.

\section{Relation between the frequency of parameters and their mean Level of Evidence score}

The mean Level of Evidence of the articles was correlated with the frequency of the parameter measured. As stated in the results section, a weak, negative and non-significant Spearman correlation was found. It is therefore possible to conclude that the frequency of measurement of a parameter is not related to the mean Level of Evidence of the articles which measure this parameter.

\section{Most relevant biomechanical parameters}

Spatio-temporal parameters, namely walking velocity, cadence and step and stride length, appear to be the most relevant biomechanical parameters in both individuals with a transtibial amputation and healthy adults. In addition, walking velocity is of even greater relevance since it also measures, and has a direct effect on such parameters as cadence and stride length.

Additionally, these spatio-temporal parameters have a certain ease of measurement: measuring simple spatio-temporal parameters such as walking velocity would appear to be an effective and simple manner to add objectivity to clinical gait analysis which is primarily aimed at ease of measurement $[8,13,14]$.

Future studies should aim to identify if the most relevant biomechanical parameters for gait analysis found in healthy adults are also relevant to other clinical populations. Individuals with a transtibial amputation and healthy adults yielded the same most relevant parameters, but perhaps the results obtained in other populations would be different, such as in populations with a neurological disorder (i.e.: Parkinson's, Stroke or Cerebral Palsy) or with a more severe mechanical impairment (i.e.: bilateral trans-femoral amputation).

\section{Conclusion}

A systematic review of the literature pertaining to healthy adult gait was performed and the most relevant biomechanical parameters were identified. Spatio-temporal parameters were those parameters most often measured and by the most amount of articles. Additionally, many specific spatio-temporal parameters were those most often measured (walking velocity, cadence and step/stride length), walking velocity being 
Roberts et al. Physical Therapy and Rehabilitation 2017,

measured most often, and by the greatest number of articles. Walking velocity, and other spatio-temporal parameters would therefore appear to be the most relevant biomechanical parameters to healthy adult gait analysis.

To our knowledge, this is a first systematic review of its kind in a healthy adult population and the implications of these findings are important for choosing the most relevant biomechanical parameters for gait analysis.

\section{Competing interests}

The authors declare that they have no competing interests.

Authors' contributions

\begin{tabular}{|l|c|c|c|}
\hline Authors' contributions & MR & DM & FP \\
\hline Research concept and design & $\checkmark$ & $\checkmark$ & $\checkmark$ \\
\hline Collection and/or assembly of data & $\checkmark$ & $\checkmark$ & -- \\
\hline Data analysis and interpretation & $\checkmark$ & $\checkmark$ & $\checkmark$ \\
\hline Writing the article & $\checkmark$ & $\checkmark$ & -- \\
\hline Critical revision of the article & $\checkmark$ & $\checkmark$ & $\checkmark$ \\
\hline Final approval of article & $\checkmark$ & -- & $\checkmark$ \\
\hline Statistical analysis & $\checkmark$ & -- & -- \\
\hline
\end{tabular}

\section{Acknowledgement}

We would like to thank the Programme de collaboration

Université-Collège du MERST for their financial support.

\section{Publication history}

Editor: Mohammad H. Hadadzadeh, Wheeling Jesuit University, USA. Received: 23-Feb-2017 Final Revised: 26-Apr-2017

Accepted: 24-Jul-2017 Published: 17-Aug-2017

\section{References}

1. Winter DA. Energy generation and absorption at the ankle and knee during fast, natural, and slow cadences. Clin Orthop Relat Res. 1983; 147-54. | PubMed

2. Schuna JM Jr and Tudor-Locke C. Step by step: accumulated knowledge and future directions of step-defined ambulatory activity. Res Exerc Epidemiol. 2012; 14:107-116. | Pdf

3. Schmid S, Schweizer K, Romkes J, Lorenzetti S and Brunner R. Secondary gait deviations in patients with and without neurological involvement: a systematic review. Gait Posture. 2013; 37:480-93. | Article | PubMed

4. Sutherland $\mathrm{DH}$. The evolution of clinical gait analysis part I: kinesiological EMG. Gait Posture. 2001; 14:61-70. | Article | PubMed

5. Gage JR. Gait analysis. An essential tool in the treatment of cerebral palsy. Clin Orthop Relat Res. 1993; 126-34. I PubMed

6. Patterson KK, Nadkarni NK, Black SE and Mcllroy WE. Gait symmetry and velocity differ in their relationship to age. Gait Posture. 2012; 35:590-4. | Article | PubMed Abstract | PubMed FullText

7. Ehara Y, Fujimoto H, Miyazaki S, Mochimaru M, Tanaka S and Yamamoto S. Comparison of the performance of 3D camera systems. Gait Posture. 1997; 5:251-5. | Article

8. Carse B, Meadows B, Bowers R and Rowe P. Affordable clinical gait analysis: an assessment of the marker tracking accuracy of a new lowcost optical 3D motion analysis system. Physiotherapy. 2013; 99:347-51. | Article | PubMed

9. Richards JG. The measurement of human motion: a comparison of commercially available systems. Hum Mov Sci. 1999; 25:589-602. | Article

10. Schwartz MH, Trost JP and Wervey RA. Measurement and management of errors in quantitative gait data. Gait Posture. 2004; 20:196-203. Article | PubMed

11. Lord SE, Halligan PW and Wade DT. Visual gait analysis: the development of a clinical assessment and scale. Clin Rehabil. 1998; 12:107-19. | Article | PubMed

12. Coutts F. Gait analysis in the therapeutic environment. Man Ther. 1999; 4:2-10. I PubMed

13. Krebs DE, Edelstein JE and Fishman S. Reliability of Observational Kinematic Gait Analysis. J Orthop Sports Phys Ther. 2014; 97:1027-33.

14. Simon SR. Quantification of human motion: gait analysis-benefits and limitations to its application to clinical problems. J Biomech. 2004; 37:1869-80. | Article | PubMed

15. Davis RB III, Õunpuu S, Tyburski D and Gage JR. A gait analysis data collection and reduction technique. Hum Mov Sci. 1991; 10:575-87. Article

16. Winter DA, Patla AE, Frank JS and Walt SE. Biomechanical walking pattern changes in the fit and healthy elderly. Phys Ther. 1990; 70:3407. | PubMed

17. Stanic U, Bajd T, Valencic V, Kljajic M and Acimovic R. Standardization of kinematic gait measurements and automatic pathological gait pattern diagnostics. Scand J Rehabil Med. 1977; 9:95-105. | PubMed

18. Sagawa $Y$, Jr., Turcot $K$, Armand $S$, Thevenon $A$, Vuillerme $N$ and Watelain E. Biomechanics and physiological parameters during gait in lower-limb amputees: a systematic review. Gait Posture. 2011; 33:511-26. | Article I PubMed

19. Liberati A, Altman DG, Tetzlaff J, Mulrow C, Gøtzsche PC and loannidis JPA et al. The PRISMA statement for reporting systematic reviews and meta-analyses of studies that evaluate health care interventions: explanation and elaboration. BMJ. 2009; 339. | Article

20. Al-Obaidi S, Wall JC, Al-Yaqoub A and Al-Ghanim M. Basic gait parameters: a comparison of reference data for normal subjects 20 to 29 years of age from Kuwait and Scandinavia. J Rehabil Res Dev. 2003; 40:361-6. | Article | PubMed

21. Allard $P$, Lachance $R$, Aissaoui $R$ and Duhaime M. Simultaneous bilateral 3-D able-bodied gait. Hum Mov Sci. 1996; 15:327-346. | Article

22. Alton F, Baldey L, Caplan S and Morrissey MC. A kinematic comparison of overground and treadmill walking. Clin Biomech (Bristol, Avon). 1998; 13:434-440. | Article | PubMed

23. Bechard DJ, Birmingham TB, Zecevic AA and Jenkyn TR. Time-varying behaviour, test-retest reliability and concurrent validity of lateral trunk lean and toe-out angles during prolonged treadmill walking. Gait Posture. 2011; 34:81-5. | Article | PubMed

24. Bennett BC, Russell SD, Sheth P and Abel MF. Angular momentum of walking at different speeds. Hum Mov Sci. 2010; 29:114-24. | Article | PubMed

25. Bollens B, Crevecoeur F, Nguyen V, Detrembleur C and Lejeune T. Does human gait exhibit comparable and reproducible long-range autocorrelations on level ground and on treadmill? Gait Posture. 2010; 32:369-73. | Article | PubMed

26. Breniere $Y$. Differential method of characterizing gait strategies from step lengths and frequencies: strategy of velocity modulation. J Mot Behav. 2003; 35:215-20. | Article | PubMed

27. Chiu MC, Wu HC and Chang LY. Gait speed and gender effects on center of pressure progression during normal walking. Gait Posture. 2013; 37:43-8. | Article | PubMed

28. Cho SH, Park JM and Kwon OY. Gender differences in three dimensional gait analysis data from $\mathbf{9 8}$ healthy Korean adults. Clin Biomech (Bristol, Avon). 2004; 19:145-52. | Article | PubMed

29. Chockalingam N, Chatterley F, Healy AC, Greenhalgh A and Branthwaite HR. Comparison of pelvic complex kinematics during treadmill and overground walking. Arch Phys Med Rehabil. 2012; 93:2302-8. | Article I PubMed

30. Chung MJ and Wang MJ. The change of gait parameters during walking at different percentage of preferred walking speed for healthy adults aged 20-60 years. Gait Posture. 2010; 31:131-5. | Article | PubMed 
Roberts et al. Physical Therapy and Rehabilitation 2017,

31. Cromwell RL, Aadland-Monahan TK, Nelson AT, Stern-Sylvestre SM and Seder B. Sagittal plane analysis of head, neck, and trunk kinematics and electromyographic activity during locomotion. J Orthop Sports Phys Ther. 2001; 31:255-62. | Article | PubMed

32. Dingwell JB, Cusumano JP, Cavanagh PR and Sternad D. Local dynamic stability versus kinematic variability of continuous overground and treadmill walking. J Biomech Eng. 2001; 123:27-32. | Article I PubMed

33. Dubbeldam R, Buurke JH, Simons C, Groothuis-Oudshoorn CG, Baan H, Nene AV and Hermens HJ. The effects of walking speed on forefoot, hindfoot and ankle joint motion. Clin Biomech (Bristol, Avon). 2010; 25:796-801. | Article | PubMed

34. Dumas R and Cheze L. Hip and knee joints are more stabilized than driven during the stance phase of gait: an analysis of the 3D angle between joint moment and joint angular velocity. Gait Posture. 2008; 28:243-50. | Article | PubMed

35. Eke-Okoro ST. Velocity field diagram of human gait. Clin Biomech (Bristol, Avon). 1989; 4:92-6. | Article | PubMed

36. Frigo $C$, Crenna $P$ and Jensen LM. Moment-angle relationship at lower limb joints during human walking at different velocities. J Electromyogr Kinesiol. 1996; 6:177-90. | Article | PubMed

37. Gabriel RC, Abrantes J, Granata K, Bulas-Cruz J, Melo-Pinto P and Filipe V. Dynamic joint stiffness of the ankle during walking: gender-related differences. Phys Ther Sport. 2008; 9:16-24. I Article I PubMed

38. Giakas $\mathrm{G}$ and Baltzopoulos V. Time and frequency domain analysis of ground reaction forces during walking: an investigation of variability and symmetry. Gait Posture. 1997; 5:189-197. | Article

39. Gillet C, Duboy J, Barbier F, Armand S, Jeddi R, Lepoutre FX and Allard P. Contribution of accelerated body masses to able-bodied gait. Am J Phys Med Rehabil. 2003; 82:101-9. | Article | PubMed

40. Goble DJ, Marino GW and Potvin JR. The influence of horizontal velocity on interlimb symmetry in normal walking. Hum Mov Sci. 2003; 22:27183. | Article | PubMed

41. Gundersen LA, Valle DR, Barr AE, Danoff JV, Stanhope SJ and SnyderMackler L. Bilateral analysis of the knee and ankle during gait: an examination of the relationship between lateral dominance and symmetry. Phys Ther. 1989; 69:640-50. I PubMed

42. Hausdorff JM, Purdon PL, Peng CK. Fractal dynamics of human gait: stability of long-range correlations in stride interval fluctuations.J App/ Physiol 1985, 80: 1448-57. | Article | PubMed

43. Jordan K, Challis JH and Newell KM. Walking speed influences on gait cycle variability. Gait Posture. 2007; 26:128-34. | Article | PubMed

44. Kavanagh JJ. Lower trunk motion and speed-dependence during walking. J Neuroeng Rehabil. 2009; 6:9. | Article | PubMed Abstract | PubMed FullText

45. Kavanagh JJ, Morrison S and Barrett RS. Coordination of head and trunk accelerations during walking. Eur J Appl Physiol. 2005; 94:468-75. | Article I PubMed

46. Keenan GS, Franz JR, Dicharry J, Della Croce U and Kerrigan DC. Lower limb joint kinetics in walking: the role of industry recommended footwear. Gait Posture. 2011; 33:350-5. I Article | PubMed

47. Kerrigan DC, Riley PO, Nieto TJ and Della Croce U. Knee joint torques: a comparison between women and men during barefoot walking. Arch Phys Med Rehabil. 2000; 81:1162-5. | Article I PubMed

48. Kerrigan DC, Riley PO, Lelas JL and Della Croce U. Quantification of pelvic rotation as a determinant of gait. Arch Phys Med Rehabil. 2001; 82:21720. | Article | PubMed

49. Kitaoka HB, Crevoisier XM, Hansen D, Katajarvi B, Harbst K and Kaufman $K R$. Foot and ankle kinematics and ground reaction forces during ambulation. Foot Ankle Int. 2006; 27:808-13. | Article I PubMed

50. Leteneur S, Gillet C, Sadeghi H, Allard P and Barbier F. Effect of trunk inclination on lower limb joint and lumbar moments in able men during the stance phase of gait. Clin Biomech (Bristol, Avon). 2009; 24:190-5. | Article I PubMed

51. Matsas A, Taylor $\mathrm{N}$ and McBurney $\mathrm{H}$. Knee joint kinematics from familiarised treadmill walking can be generalised to overground walking in young unimpaired subjects. Gait Posture. 2000; 11:46-53. I
Article I PubMed

52. Morris ME, Bilney B, Matyas TA and Dalton GW. Short-term relationships between footstep variables in young adults. Gait Posture. 2007; 25:22935. | Article | PubMed

53. Orendurff MS, Segal AD, Klute GK, Berge JS, Rohr ES and Kadel NJ. The effect of walking speed on center of mass displacement. J Rehabil Res Dev. 2004; 41:829-34. I Article I PubMed

54. Pecoraro F, Mazza C, Zok M and Cappozzo A. Assessment of levelwalking aperiodicity. J Neuroeng Rehabil. 2006; 3:28. | Article | PubMed Abstract | PubMed FullText

55. Ratcliffe RJ and Holt KG. Low frequency shock absorption in human walking. Gait Posture. 1997; 5:93-100.

| Article

56. Riley PO, Paolini G, Della Croce U, Paylo KW and Kerrigan DC. A kinematic and kinetic comparison of overground and treadmill walking in healthy subjects. Gait Posture. 2007; 26:17-24. | $\underline{\text { Article | PubMed }}$

57. Roislien J, Skare O, Gustavsen M, Broch NL, Rennie L and Opheim A. Simultaneous estimation of effects of gender, age and walking speed on kinematic gait data. Gait Posture. 2009; 30:441-5. | Article | PubMed

58. Rutherford DJ and Hubley-Kozey C. Explaining the hip adduction moment variability during gait: Implications for hip abductor strengthening. Clin Biomech (Bristol, Avon). 2009; 24:267-73. | Article | PubMed

59. Ryu T, Soon Choi H, Choi H and Chung MK. A comparison of gait characteristics between Korean and Western people for establishing Korean gait reference data. Int J Ind Ergon. 2006; 36:1023-30. | Article

60. Sadeghi H, Sadeghi S, Allard P, Labelle H and Duhaime M. Lower limb muscle power relationships in bilateral able-bodied gait. Am J Phys Med Rehabil. 2001; 80:821-30. | Article | PubMed

61. Sadeghi H. Contributions of lower-limb muscle power in gait of people without impairments. Phys Ther. 2000; 80:1188-96. | PubMed

62. Sadeghi H, Sadeghi S, Prince F, Allard P, Labelle H and Vaughan CL. Functional roles of ankle and hip sagittal muscle moments in ablebodied gait. Clin Biomech (Bristol, Avon). 2001; 16:688-95. | Article | PubMed

63. Sadeghi H, Allard P, Lachance R, Aissaoui R, Sadeghi S, Perrault R and Duhaime M. Relationship between ankle frontal muscle powers and three-d gait patterns. Am J Phys Med Rehabil. 2002; 81:429-36. | Article | PubMed

64. Seeley MK, Umberger BR and Shapiro R. A test of the functional asymmetry hypothesis in walking. Gait Posture. 2008; 28:24-8. | Article | PubMed

65. Sekiya $\mathrm{N}$ and Nagasaki $\mathrm{H}$. Reproducibility of the walking patterns of normal young adults: test-retest reliability of the walk ratio(steplength/step-rate). Gait Posture. 1998; 7:225-227. I Article I PubMed

66. Sekiya N, Nagasaki H, Ito $\mathrm{H}$ and Furuna T. Optimal walking in terms of variability in step length. J Orthop Sports Phys Ther. 1997; 26:266-72. | Article | PubMed

67. Shemmell J, Johansson J, Portra V, Gottlieb GL, Thomas JS and Corcos DM. Control of interjoint coordination during the swing phase of normal gait at different speeds. J Neuroeng Rehabil. 2007; 4:10. | Article | PubMed Abstract | PubMed FullText

68. Son K, Park J and Park S. Variability analysis of lower extremity joint kinematics during walking in healthy young adults. Med Eng Phys. 2009; 31:784-92. | Article | PubMed

69. Svensson OK and Weidenhielm L. Variability of knee moment arms in the frontal and sagittal planes during normal gait. Clin Biomech (Bristol, Avon). 1993; 8:59-65. | Article I PubMed

70. Taylor NF, Evans OM and Goldie PA. Angular movements of the lumbar spine and pelvis can be reliably measured after 4 minutes of treadmill walking. Clin Biomech (Bristol, Avon). 1996; 11:484-486. | Article | PubMed

71. Taylor NF, Goldie PA and Evans OM. Angular movements of the pelvis and lumbar spine during self-selected and slow walking speeds. Gait Posture. 1999; 9:88-94. | Article | PubMed 
Roberts et al. Physical Therapy and Rehabilitation 2017, http://www.hoajonline.com/journals/pdf/2055-2386-4-6.pdf

72. Teixeira-Salmela LF, Nadeau S, Milot MH, Gravel D and Requiao LF. Effects of cadence on energy generation and absorption at lower extremity joints during gait. Clin Biomech (Bristol, Avon). 2008; 23:769-78. | Article I PubMed

73. Tesio L, Lanzi D and Detrembleur C. The 3-D motion of the centre of gravity of the human body during level walking. I. Normal subjects at low and intermediate walking speeds. Clin Biomech (Bristol, Avon). 1998; 13:77-82. | Article | PubMed

74. Tesio $L$, Rota $V$ and Perucca $L$. The 3D trajectory of the body centre of mass during adult human walking: evidence for a speed-curvature power law. J Biomech. 2011; 44:732-40. | Article | PubMed

75. Titianova EB, Mateev PS and Tarkka IM. Footprint analysis of gait using a pressure sensor system. J Electromyogr Kinesiol. 2004; 14:275-81. | Article | PubMed

76. Vardaxis VG, Allard P and Lachance R. Classification of able-bodied gait using 3-D muscle powers. Hum Mov Sci. 1998; 17:121-136. I Article

77. Vogt L, Pfeifer K and Banzer W. Comparison of angular lumbar spine and pelvis kinematics during treadmill and overground locomotion. Clin Biomech (Bristol, Avon). 2002; 17:162-5. | Article I PubMed

78. Wang $Y$ and Watanabe $K$. Limb dominance related to the variability and symmetry of the vertical ground reaction force and center of pressure. $J$ Appl Biomech. 2012; 28:473-8. I PubMed

79. Warabi T, Kato M, Kiriyama K, Yoshida T and Kobayashi N. Treadmill walking and overground walking of human subjects compared by recording sole-floor reaction force. Neurosci Res. 2005; 53:343-8. | Article I PubMed

80. White SC, Yack HJ, Tucker CA and Lin HY. Comparison of vertical ground reaction forces during overground and treadmill walking. Med Sci Sports Exerc. 1998; 30:1537-42. | Article I PubMed

81. Whittington B, Silder A, Heiderscheit B and Thelen DG. The contribution of passive-elastic mechanisms to lower extremity joint kinetics during human walking. Gait Posture. 2008; 27:628-34. | Article I PubMed Abstract | PubMed FullText

82. van Schooten KS, Rispens SM, Elders PJ, van Dieen JH and Pijnappels $M$. Toward ambulatory balance assessment: estimating variability and stability from short bouts of gait. Gait Posture. 2014; 39:695-9. | PubMed

83. Clark RA, Bower KJ, Mentiplay BF, Paterson K and Pua YH. Concurrent validity of the Microsoft Kinect for assessment of spatiotemporal gait variables. J Biomech. 2013; 46:2722-5. | Article | PubMed

84. Pataky TC, Robinson MA, Vanrenterghem J, Savage R, Bates KT and Crompton RH. Vector field statistics for objective center-of-pressure trajectory analysis during gait, with evidence of scalar sensitivity to small coordinate system rotations. Gait Posture. 2014; 40:255-8. | Article | PubMed

\section{Citation:}

Roberts M, Mongeon D and Prince F. Biomechanical parameters for gait analysis: a systematic review of healthy human gait. Phys Ther Rehabil. 2017; 4:6. http://dx.doi.org/10.7243/2055-2386-4-6 